\title{
HAK AHLI WARIS WARGA NEGARA ASING ATAS OBYEK WARIS BERUPA SAHAM PERSEROAN TERBATAS PENANAMAN MODAL DALAM NEGERI
}

\author{
Amadeo Tito Sebastian ${ }^{1}$; HabibAdjie $^{2}$ \\ ${ }^{1}$ Mahasiswa Magister Kenotariatan, Fakultas Hukum Universitas Narotama \\ Jl. Arief Rahman Hakim 51 Surabaya \\ E-mail : amadeo.tito2018@gmail.com \\ ${ }^{2}$ Dosen Magister Kenotariatan, Fakultas Hukum Universitas Narotama \\ Jl. Arief Rahman Hakim 51 Surabaya \\ E-mail : adjieku61@gmail.com
}

\begin{abstract}
Regulation about capital investment in Indonesia divided into domestic and foreign capital investment. Limited company that is included as domestic capital investment shall be owned $100 \%$ by Indonesian citizen. A limited company stock is a moving object which can be inherited and switched to beneficiary including foreigners as the heir. The present study tries to analyze and elaborate further about foreigner rights as beneficiary over capital investment shares of limited company. Moreover, the present study also tries to examine legal position of domestic capital investment shares of the limited company when transition of shares holder is conducted to foreigner as the beneficiary. The method used in the present study is a normative legal research, namely legal research which is conducted by examining the library materials or secondary law while in finding and collecting the data is done by two approaches, namely the law and conceptual approaches. The present study concluded that citizenship status cannot preclude someone to become beneficiary. Foreigner who becomes beneficiary for domestic capital investment shares of the limited company shall be given opportunity or limited time to divert the heirs to Indonesian citizen or he/she shall change the citizenship status as Indonesian citizen. The domestic limited company that is owned by foreigner because of beneficiary status shall switch the company status into foreign investment company.
\end{abstract}

Keywords: Heritage, Stocks, Capital Investment.

\begin{abstract}
Abstrak
Pengaturan mengenai penanaman modal di Indonesia terbagi atas penanaman modal dalam negeri dan penanaman modal asing. Pada Perseroan Terbatas yang termasuk jenis Perseroan Terbatas Penanaman Modal Dalam Negeri mengharuskan $100 \%$ modal yang umumnya dirupakan saham dalam perseroan dimiliki oleh Warga Negara Indonesia. Saham Perseroan Terbatas merupakan benda bergerak yang dapat menjadi obyek waris dan beralih kepada ahli waris yang berkewarganegaraan asing. Penelitian ini ingin menelaah dan menganalisa lebih lanjut apakah ahli waris Warga Negara Asing berhak atas warisan berupa saham Perseroan Terbatas Penanaman Modal Dalam Negeri serta bagaimana kedudukan Perseroan Terbatas Penanaman Modal Dalam Negeri setelah terjadi peralihan saham karena pewarisan kepada Warga Negara Asing. Metode penelitian yang digunakan adalah penelitian hukum normatif, yaitu penelitian hukum yang dilakukan dengan cara meneliti bahan pustaka atau bahan hukum sekunder sedangkan pendekatan masalah dilakukan dengan menggunakan pendekatan undang-undang dan pendekatan konseptual. Hasil penelitian menunjukkan bahwa kewarganegaraan seseorang tidak menghalangi hak untuk menjadi ahli waris. Atas warisan berupa saham dalam perseroan terbatas penanaman modal dalam negeri maka ahli waris
\end{abstract}


berkewarganegaraan asing harus diberikan waktu tertentu untuk mengalihkan saham tersebut kepada warga negara Indonesia atau mengubah kewarganegaraannya menjadi warga negara Indonesia. Perseroan Terbatas Penanaman Modal Dalam Negeri yang sahamnya beralih kepada Warga Negara Asing harus mengubah status perusahaannya menjadi penanaman modal asing.

Kata Kunci: Warisan, Saham, Penanaman Modal.

\section{LATAR BELAKANG}

Aktivitas dari suatu badan usaha berbentuk Perseroan Terbatas sangat ditentukan oleh kedudukan Pemegang Saham. Pemegang Saham dalam Perseroan Terbatas merupakan orang yang melakukan kegiatan penanaman modal dalam suatu badan usaha yang berbentuk Perseroan Terbatas. ${ }^{1}$ Segala kegiatan yang berkaitan dengan Perseroan Terbatas di Indonesia telah diatur dalam UndangUndang Nomor 40 Tahun 2007 Tentang Pemegang Saham Perseroan Terbatas (selanjutnya ditulis UUPT). ${ }^{2}$ Namun demikian, UUPT tidak mengatur secara jelas dan tegas ketentuan mengenai siapa saja yang dapat menjadi Pemegang Saham. Dalam UUPT masih terdapat kekaburan norma mengenai kedudukan Pemegang Saham dalam Perseroan Terbatas, apakah hanya terbatas pada Warga Negara Indonesia atau dapat juga dipegang oleh Warga Negara Asing.

\footnotetext{
${ }^{1}$ Tuti Rastuti, Seluk Beluk Perusahaan Dan Hukum Perusahaan, Refika Aditama, Bandung, 2015, hlm. 31.

${ }^{2}$ Habib Adjie, Penggabungan Peleburan \& Pengambil Alihan Dalam Perseroan Terbatas, Mandar Maju, Bandung, 2003, hlm. 27.
}

Dalam keterkaitan dengan status kewarganegaraan pemegang saham Perseroan Terbatas mempengaruhi adanya perbedaan status permodalan Perseroan Terbatas tersebut. Apabila pemegang saham Perseroan Terbatas tersebut adalah Warga Negara Indonesia, maka status Permodalannya adalah Penanaman Modal Dalam Negeri yang tunduk pada UUPT. ${ }^{3}$ Sedangkan apabila kewarganegaraan pemegang saham Perseroan Terbatas tersebut dimiliki oleh warga negara asing, maka status permodalan Perseroan Terbatas tersebut adalah Penanaman Modal Asing yang tidak hanya tunduk pada peraturan umum pada UUPT malainkan juga selanjutnya terdapat pembatasan-pembatasan yang terdapat dalam beberapa Perturan PerundangUndangan antara lain : Undang-Undang Nomor 25 Tahun 2007 Tentang Penanaman Modal (UU Penanaman Modal), Undang-Undang Nomor 20 Tahun 2008 Tentang Usaha Mikro, Kecil, Dan Menengah (UU UMKM) dan

3 Rudhi Prasetya, Perseroan Terbatas : Teori Dan Praktek, Sinar Grafika, Jakarta, 2016, hlm. 16. 
Peraturan Presiden Republik Indonesia Nomor 44 Tahun 2016 Tentang Daftar Bidang Usaha Yang Tertutup Dan Bidang Usaha Yang Terbuka Dengan Persyaratan Dibidang Penanaman Modal (UU Perpres 44/2016).

Hal tersebut tidak kalah bergolaknya, ketika perpindahtanganan suatu saham Perseroan Terbatas akibat suatu peristiwa hukum, yaitu kematian yang mengakibatkan saham tersebut berpindah tangan kepada ahli waris pemegang saham akan dapat menimbulkan persoalan hukum, karena tidak ada peraturan yang secara jelas mengatur tentang perpindahan hak atas saham Perseroan Terbatas atas dasar kewarisan yang ahli warisnya merupakan Warga Negara Asing akan menimbulkan masalah hukum. hal inilah yang penulis secara ilmiah ingin meneliti apakah ahli waris Warga Negara Asing berhak atas warisan berupa saham Perseroan Terbatas Penanaman Modal Dalam Negeri. karena akan terjadi persoalan hukum, dimana akibat hukum yang terjadi adalah apabila ada $1 \%$ pemegang saham suatu Perseroan Terbatas maka secara otomatis Perseroan Terbatas Tersebut akan berubah statusnya menjadi Perseroan Terbatas Penanaman Modal Asing.

Kepemilikan saham dalam Perseroan Terbatas dapat dipindahtangankan Sesuai dengan Pasal 60 ayat (1) UUPT, saham diklasifikasikan sebagai benda bergerak, sehingga kepemilikannya dapat dipindahtangankan baik dengan suatu perbuatan hukum dalam hal ini jual beli maupun dengan adanya suatu peristiwa hukum akibat dari kematian. Apabila terjadi perpindahan pemegang saham yang dikarenakan oleh suatu peristiwa hukum yakni kematian yang ahli warisnya adalah seorang warga negara asing, maka akan ada permasalahan hukum dimana perseroan terbatas tersebut mempunyai kewajiban baru yang secara "tiba-tiba" muncul untuk melakukan penyesuaian permodalannya dan perjinan sesuai dengan peraturan tentang Perseroan Terbatas Penanaman Modal Asing yang semuanya itu berbeda dengan Perseroan Terbatas Penanaman Modal Dalam Negeri yang telah dimilikinya sebelum adanya perpindahan saham tersebut.

Adanya perubahan tersebut diatas dapat menimbulkan permasalahan hukum antara pemegang saham lain yang berkewarganegaraan Indonesia tidak sepakat apabila Perseroan Terbatas Tersebut berubah status permodalannya menjadi penanaman modal asing karena adanya kewajiban-kewajiban baru yang dirasa memberatkan pemegang saham yang lainnya. Sedangkan adanya hak Ahli 
Waris warga negara asing salah satu pemegang saham yang telah meninggal yang oleh negara harus dilindungi hak kebendaannya.

\section{RUMUSAN MASALAH}

Berdasarkan pada latar belakang yang sebagaimana telah dijabarkan diatas, maka dapat dirumuskan permasalahan hukum antara lain sebagai berikut :

1. Apakah ahli waris Warga Negara Asing berhak atas warisan berupa saham Perseroan Terbatas?

2. Apa upaya penyelesaian bagi Perseron Terbatas Penanaman Modal Dalam Negeri yang sahamnya beralih karena pewarisan kepada Warga Negara Asing?

\section{METODE PENELITIAN}

Secara hakikat, ilmu hukum berusaha untuk menampilkan hukum secara integral. ${ }^{4}$ Penelitian ini merupakan penelitian hukum normatif (Normative Legal Research), yaitu penelitian yang dilakukan dengan cara mengkaji Peraturan Perundang-Undangan yang berlaku atau diterapkan terhadap suatu permasalahan tertentu. Pendekatan yang digunakan

4, Nurhayati, Yati. "Perdebatan antara Metode Normatif dengan Metode Empirik dalam Penelitian Ilmu Hukum Ditinjau dari Karakter, Fungsi, dan Tujuan Ilmu Hukum." Al Adl: Jurnal Hukum5.10 (2013), hlm. 15. untuk menganalisa permasalahan dalam penelitian adalah pendekatan perundangundangan (statute approach) yaitu pendekatan yang dilakukan dengan menelaah semua Undang-Undang serta regulasi yang bersangkut paut dengan isu hukum yang sedang ditangani dan pendekatan konsep (conceptual approach) yaitu pendekatan yang beranjak dari pandangan-pandangan dan doktrin-doktrin yang berkembang dalam ilmu hukum. Dengan mempelajari pandanganpandangan dan doktrin-doktrin dalam ilmu hukum, peneliti akan menemukan ide-ide yang melahirkan pengertianpengertian hukum, konsep-konsep hukum, dan asas-asas hukumyang relevan dengan isu hukum yang dihadapi. ${ }^{5}$

\section{PEMBAHASAN}

Hak Ahli Waris Warga Negara Asing Atas Warisan Berupa Saham Perseroan Terbatas

Pewarisan dimaknai sebagai pemindahan harta peninggalan dari orang yang meninggal dunia kepada ahli warisnya. Dalam hukum waris yang berlaku di Indonesia baik itu hukum waris perdata, hukum waris islam maupun hukum waris adat menempatkan anakanak dari pewaris sebagai golongan ahli

5 Peter Mahmud Marzuki, Penelitian Hukum, Kencana Prenada Media Group, Jakarta, 2005, hlm. 95-97. 
waris yang utama, dalam, arti sanak saudara yang lain tidak menjadi ahli waris apabila pada saat meninggal dunia pewaris memiliki anak-anak. ${ }^{6}$ Perkawinan sendiri dalam Undang-Undnag Nomor 1 Tahun 1974 dikenal adanya perkawinan campuran yang berakibat terhadap status kewarganegaraan anak dari hasil perkawinan campuran atau juga status hak waris. $^{7}$

Ketentuan mengenai pewarisan di Indonesia bersifat plural. Secara umum ketentuan mengenai pewarisan di Indonesia diatur dalam hukum waris perdata, hukum waris islam dan hukum waris adat. Abdulkadir Muhammad mendefinisikan hukum waris sebagai segala peraturan hukum yang mengatur tentang beralihnya harta pewarisan dari pewaris karena kematian kepada ahli waris atau orang yang ditunjuk. Dari rumusan ini dapat diketahui unsur-unsur yang terdapat dalam pengertian hukum waris terdiri dari subjek hukum waris,

${ }^{6}$ Ika Febriasari Dan Afdol, "Kedudukan Keponakan Sebagai Ahli Waris Pengganti Dalam Sengketa Waris Melawan Anak Angkat Penerima Wasiat Wajibah", Jurnal Al-Adl, Volume X Nomor 1, Januari 2018 , hlm. 69-88.

7 Yati Nurhayati dan Ifrani, "The Legal Consequences Regarding The Execution Of Joint Property Land Obtained Due Transnatiional Marriage In Indonesian Positive Law" Lambung Mangkurat Law Journal, Vol. 3 Issue 1, March (2018), hlm. 127. peristiwa hukum waris, hubungan hukum waris, dan objek hukum waris. ${ }^{8}$

Pendapat lain dikemukakan oleh A. Pitlo sebagaimana dikutip oleh Sudikno Mertokusumo, yang berpendapat bahwa hukum waris merupakan kumpulan peraturan yang mengatur hukum mengenai kekayaan karena wafatnya seseorang, yaitu mengenai pemindahan kekayaan yang ditinggalkan oleh si mati dan akibat dari pemindahan ini bagi orang-orang yang memperolehnya, baik dalam hubungan antara mereka dengan mereka, maupun dalam hubungan antar mereka dengan pihak ketiga. ${ }^{9}$

Proses peralihan harta kekayaan dari orang yang telah mati kepada yang masih hidup dalam Hukum Waris terdapat unsur-unsur sebagai berikut: 1) Pewaris,yaitu orang yang meninggal dunia dan meninggalkan harta kekayaan pada orang yang masih hidup. Dalam pengertian ini unsur yang penting ialah unsur harta kekayaan dan unsur orang yang masih hidup. Unsur meninggalnya orang tidak perlu dipersoalkan sebabnya; 2) Harta Warisan, yaitu adalah segala harta kekayaan yang ditinggalkan oleh pewaris setelah dikurangi dengan semua

${ }^{8}$ Abdulkadir Muhammad, Hukum Perdata Indonesia, Citra Aditya Bakti, Bandung, 2007, hlm. 267.

${ }^{9}$ Sudikno Mertokusumo, Mengenal Hukum : Suatu Pengantar. Liberty, Yogyakarta, 2002, hlm. 180 . 
hutangnya. Harta warisan ini menjadi hak ahli waris; 3) Ahli Waris, yaitu setiap orang yang berhak atas harta peninggalan pewaris. $^{10}$

Mengenai siapa saja yang menjadi ahli waris disebutkan dalam Pasal 852 BW: "Menurut undang-undang, yang berhak menjadi ahli waris ialah keluarga sedarah, baik yang sah menurut undangundang maupun yang di luar perkawinan, dan suami atau isteri yang hidup terlama, menurut peraturan-peraturan berikut ini". Bagi pemeluk agama Islam diatur pula mengenai siapa saja yang dapat menjadi ahli waris dalam Pasal 171 huruf c KHI yang menyatakan: "Ahli waris adalah orang yang pada saat meninggal dunia mempunyai hubungan darah atau hubungan perkawinan dengan pewaris, beragama Islam dan tidak terhalang karena hukum untuk menjadi ahli waris".

Dari ketentuan tersebut diatas dapat diketahui bahwa untuk menjadi ahli waris hanya cukup ditentukan dengan adanya hubungan darah atau hubungan perkawinan. Dalam aturan yang bersifat Lex Specialis mengenai perkawinan yaitu Undang-Undang Nomor 1 Tahun 21974 Tentang Perkawinan (UU Perkawinan) diatur pula dalam bagian ketiga Pasal 57 UU Perkawinan mengenai perkawinan 280-282. campuran, yaitu perkawinan antara dua orang yang di Indonesia tunduk pada hukum yang berlainan, karena perbedaan kewarganegaraan dan salah satu pihak berkewarganegaraan Indonesia. Adanya ketentuan tersebut menempatkan perkawinan campuran termasuk pula kedalam perkawinan yang sah menurut hukum sehingga terpenuhilah rumusan bahwa ahli waris dapat terjadi karena hubungan perkawinan tanpa membedakan kewarganegaraan. Selanjutnya mengenai ahli waris karena hubungan darah, dari terjadinya perkawinan tersebut membawa konsekuensi akan terjadi hubungan keperdataan bagi anak-anak yang dilahirkan dalam perkawinan tersebut. Hubungan keperdataan ini termasuk pula dalam hal waris.

Kegiatan dalam hal pewarisan tidak terlepas dari kehidupan masyarakat yang terus berkembang, terlihat pada jenis harta kekayaan yang menjadi objek dari pewarisan ialah berupa saham dari suatu perseroan yang merupakan benda tidak berwujud dan terdapat ketentuan khusus dalam peralihannya. Pasal 31 ayat (1) UUPT menjelaskan bahwa "Modal dasar Perseroan terdiri atas seluruh nilai nominal saham." Jadi dapat disimpulkan bahwa saham menjadi modal dasar dari pembentukan suatu badan hukum dari Perseroan yang termuat dalam anggaran 
dasar perseroan terbatas. ${ }^{11}$ Badan hukum disini maksudnya adalah suatu badan atau organ yang memiliki status, kedudukan, kewenangan yang sama seperti manusia. ${ }^{12}$

Menurut Hatta Isnaini Wahyu Utomo, saham sebagaimana disebutkan dalam Pasal 60 ayat (1) UUPT merupakan benda bergerak. Pada bagian penjelasan Pasal 60 ayat (1) UUPT disebutkan bahwa kepemilikan atas saham sebagai benda bergerak memberikan hak kebendaan (vermogensrecht) kepada pemiliknya. Hak kebendaan merupakan hak yang mutlak atas sesuatu benda di mana hak itu memberikan kekuasaan langsung atas sesuatu benda dan dapat dipertahankan terhadap siapapun. ${ }^{13}$

Pendapat serupa dikemukakan oleh Yahya Harahap, karena saham merupakan benda bergerak maka harus tunduk kepada ketentuan Pasal 1977 BW yang mengatur prinsip besit atas benda bergerak merupakan titel yang sempurna (bezit geldt als volko men titel, passession

11 Man. S. Sastrawidjaja, Perseroan Terbatas Menurut Tiga Undang-Undang, Alumni, Bandung, 2008, hlm. 78.

${ }^{12}$ Yati Nurhayati, "Tinjauan Yuridis Terhadap BUMN Yang Berbentuk Perseroaan Terbatas (PT) Dalam Perkara Kepailitan Dihubungkan Dengan Asas Kapastian Hukum," Jurnal Al - Ulum Vol. 64, No. 2 Tahun 2015, hlm. 42.

https://ojs.uniska-

bjm.ac.id/index.php/ULUM/article/view/160

13 Hatta Isnaini Wahyu Utomo, "Hukum Perseroan", Bahan Ajar, Fakultas Hukum, Universitas Yos Soedarso Surabaya, 2017, hlm. 14. amounts to perfect title) dan juga pemilik saham dapat atau berhak mengalihkan, mengagunkan dan memungut hasil dari saham tersebut. ${ }^{14}$ Adanya hak kebendaan tersebut menjadikan saham sebagai obyek waris yang dapat dimiliki oleh para ahli waris. Hal ini sesuai dengan ketentuan Pasal 833 BW yang menyatakan bahwa para ahli waris, dengan sendirinya karena hukum, mendapat hak miik atas semua barang, semua hak dan semua piutang orang yang meninggal.

Saham sebagai modal dari berdirinya suatu perseroan terbatas diperoleh dari modal yang disetorkan oleh pendiri perseroan itu sendiri yang dapat beralih dalam hal pemegang hak atas saham telah meninggal dunia. Secara implisit, beberapa pasal dalam UUPT menjelaskan mengenai saham dan persyaratan dari beralihnya kepemilikan saham dari pemilik saham yang telah meninggal kepada ahli warisnya.

Beralihnya saham sebagai objek pewarisan tidak diatur secara eksplisit dalam UUPT, namun dalam Pasal 57 UUPT disebutkan :

(1) Dalam anggaran dasar dapat diatur persyaratan mengenai pemindahan hak atas saham, yaitu:

a. keharusan menawarkan terlebih dahulu kepada pemegang saham

14 Yahya Harahap, Hukum Perseroan Terbatas, Sinar Grafika, Jakarta, 2016, hlm. 274. 
dengan klasifikasi tertentu atau pemegang saham lainnya;

b. keharusan mendapatkan persetujuan terlebih dahulu dari Organ Perseroan; dan/atau

c. keharusan mendapatkan persetujuan terlebih dahulu dari instansi yang berwenang sesuai dengan ketentuan peraturan perundang-undangan.

(2) Persyaratan sebagaimana dimaksud pada ayat (1) tidak berlaku dalam hal pemindahan hak atas saham disebabkan peralihan hak karena hukum, kecuali keharusan sebagaimana dimaksud pada ayat (1) huruf $\mathrm{c}$ berkenaan dengan kewarisan.

Dari rumusan pasal tersebut diatas, pemindahan hak atas saham sebagai akibat dari peristiwa pewarisan tidak harus mendapatkan persetujuan dari organ perseroan yaitu Rapat Umum Pemegang Saham, Direksi, dan Dewan Komisaris, namun untuk kondisi tertentu harus mendapatkan persetujuan dari instansi terkait seperti Badan Pengawas Pasar Modal atau Badan Koordinasi Penanaman Modal. Hal tersebut dapat dimaknai bahwa dengan dimungkinkannya pemindahan hak atas saham sebagai akibat dari pewarisan maka saham dapat menjadi objek waris.

Pada bagian selanjutnya masih belum jelas status terkait hak ahli waris apabila saham sebagai obyek waris jatuh pada ahli waris Warga Negara Asing. Dalam hal ini dibutuhkan adanya suatu kepastian hukum. Dengan adanya kepastian hukum masyarakat akan tahu kejelasan akan hak dan kewajiban menurut hukum. Tanpa ada kepastian hukum maka orang akan tidak tahu apa yang harus diperbuat, tidak mengetahui perbuatanya benar atau salah, dilarang atau tidak dilarang oleh hukum. ${ }^{15}$

Dalam sistem hukum di Indonesia, pewarisan terjadi karena adanya hubungan darah dan hubungan perkawinan. Hal ini dapat dimaknai bahwa hukum waris di Indonesia secara umum tidak mengenal pembedaan ahli waris baik Warga Negara Indonesia ataupun Warga Negara Asing sebagai ahli warisnya. Namun dalam kaitannya dengan warisan berupa saham perseroan harus terlebih dahulu dilihat bidang usaha yang dijalankan perseroan tersebut dapat dimasuki unsur asing.

Pasal 2 ayat (1) Perpres 44/2016 menentukan bahwa bidang usaha dalam kegiatan penanaman modal terdiri atas: a) Bidang Usaha Yang Terbuka; b) Bidang Usaha Yang Tertutup; dan c) Bidang Usaha Yang Terbuka Dengan Persyaratan. Mengenai bidang usaha yang terbuka dengan persyaratan tertentu, antara lain

${ }^{15}$ Mariano Putra Prayoga Sumangkut dan Ghansham Anand, "Perbuatan Melawan Hukum Dalam Peralihan Aset Yayasan Keagamaan Yang Diperoleh Melalui Hibah Bersyarat Tanpa Akta Otentik (Kajian Putusan Nomor 2016 K/Pdt/2013)", Jurnal Al-Adl, Volume IX Nomor 3, Desember 2017, hlm. 377-357. 
terdapat ketentuan mengenai modal dalam negeri $100 \%$ dan batasan modal asing.

Dalam kaitannya dengan peralihan saham kepada Warga Negara Asing yang terjadi karena pewarisan, maka harus dilihat terlebih dahulu status perseroan tersebut apakah berupa Perseroan Terbatas Penanaman Modal Dalam Negeri atau Penanaman Modal Asing. Apabila Perseroan tersebut merupakan Penanaman Modal Asing maka hanya perlu diperhatikan mengenai batasan modal asingnya saja, apakah saham yang beralih tersebut melebihi ketentuan mengenai batasan modal asing atau tidak. Jika saham tersebut melebihi maka kelebihan dari prosentase saham tersebut harus dialihkan.

Apabila Perseroan tersebut merupakan Penanaman Modal Dalam Negeri atau yang bidang usahanya termasuk dalam bidang usaha yang dilarang atau tertutup untuk dijalankan oleh Perseroan Terbatas Penanaman Modal Asing maka dapat dilakukan penyesuaian bidang usaha dengan bidang usaha yang diperbolehkan untuk dijalankan oleh Perseroan Terbatas Penanaman Modal Asing atau dengan kata lain status Perseroan Terbatas tersebut diubah menjadi Perseroan Terbatas Penanaman Modal Asing.
Solusi lain yang dapat dilakukan adalah dengan mengalihkan saham yang berdasarkan hak waris yang sah dimiliki oleh ahli waris yang berstatus Warga Negara Asing tersebut kepada Warga Negara Indonesia. Untuk pengalihan tersebut dapat diberikan jangka waktu tertentu sampai dengan saham tersebut dialihkan kepada Warga Negara Indonesia. Apabila ditafsirkan secara

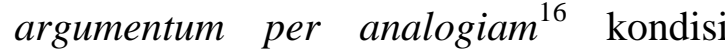
tersebut hampir serupa dengan pewarisan yang terjadi di bidang pertanahan berkaitan dengan Hak Milik yang beralih kepada Warga Negara Asing karena pewarisan atau percampuran harta. Pasal 21 ayat (3) Undang-Undang Nomor 5 Tahun 1960 Tentang Peraturan Dasar Pokok-Pokok Agraria memberikan jangka waktu satu tahun untuk mengalihkan hak milik yang diperoleh Warga Negara Asing dari pewarisan atau percampuran harta. Disamping itu juga dapat dilakukan perubahan kewarganegaraan bagi ahli waris Warga Negara Asing apabila tidak dikehendaki terjadinya perubahan status Perseroan menjadi Penanaman Modal Asing.

16 Sudikno Mertokusumo, Penemuan Hukum, Liberty, Yogyakarta, 2002, hlm. 45. 
Kedudukan Perseroan Terbatas Yang

Sahamnya Beralih Kepada Warga

\section{Negara Asing Karena Pewarisan}

Untuk dapat memperkuat perekonomian suatu negara diperlukan adanya modal yang sangat besar, dan oleh sebab itu Negara Indonesia memerlukan keikutsertaan investor-investor baik dari dalam negeri maupun luar negeri untuk menyokong perekonomian negara. Untuk mewujudkan hal tersebut Indonesia ikut serta dalam berbagai kerjasama internasional dan membentuk suatu Undang-Undang untuk melindungi dan mengatur agar kegiatan penanaman modal tidak dapat merugikan bagi Warga Negara Indonesia melalui diundangkannya UU Penanaman Modal.

Istilah penanamam modal adalah sebuah istilah yang berasal dari bahasa bahasa Inggris yaitu investment. ${ }^{17}$ Investment atau penanaman modal (investasi) berasal dari bahasa latin investire (memakai) yang diartikan berbeda-beda pengertiannya. ${ }^{18}$ Pasal 1 angka 1 UU Penanaman Modal mendefinisikan Penanaman modal sebagai segala bentuk kegiatan penanaman modal, baik oleh penanam modal dalam negeri

17 David Kairupan, Aspek Hukum Penanaman Modal Asing di Indonesia, Kencana Prenada Media , Jakarta, 2013, hlm 21.

${ }^{18}$ C.S.T. Kansil dan Cristine S.T. Kansil, Pokok-Pokok Pengetahuan Hukum Dagang Indonesia, Sinar Grafika, Jakarta, 2008, hlm. 571. maupun penanam modal asing untuk melakukan usaha di wilayah negara Republik Indonesia.

Kegiatan penanaman modal yang dilakukan orang Warga Negara Indonesia statusnya adalah Penanaman Modal Dalam Negeri dimana seluruh Pemegang saham adalah Warga Negara Indonesia. Dalam Perseroan Terbatas Penanaman Modal Dalam Negeri modal minimum suatu Perseroan Terbatas adalah sejumlah Rp. 50.000.000,00 (lima puluh juta Rupiah) atau hasil penjualannya maksimal Rp. 300.000.000 (tiga ratus juta rupiah), hal ini sesuai dengan Pasal 32 UUPT jo. Pasal 6 ayat (1) UU UMKM.

Berbeda dengan ketentuan Penanaman Modal Dalam Negeri, Penanaman Modal asing haruslah melakukan Usaha besar. Hal tersebut berdasarkan ketentuan Pasal 1 angka 4 UU Penanaman Modal yang secara eksplisit mengharuskan Penanaman Modal Asing dilakukan dalam klasifikasi Usaha Besar. Usaha Besar disini mengharuskan penanam Modal Asing mempunyai Modal awal atau Modal dasar sedikitnya Rp. 10.000.000.000,00 (sepuluh milliar Rupiah) atau hasil penjualan tahunan lebih dari Rp. 50.000.000.000,00 (lima puluh milliar Rupiah). 
Perbedaan peraturan tersebut merupakan suatu usaha pemerintah untuk melindungi pelaku-pelaku usaha mikro, kecil, dan menengah supaya dapat terus berkembang. adanya pembatasanpembatasan yang dilakukan pemerintah meliputi bidang-bidang usaha tertentu haruslah melakukan kemitraan dengan penananam modal dalam negeri dengan adanya pembatasan permodalan asing yang masuk dan juga ada bidang-bidang usaha yang tidak diperbolehkan dilakukan oleh penanaman modal asing sesuai dengan Perpres 44/2016.

Status kewarganegaran seseorang pada perkembangan dunia saat ini relatif mudah berubah. Hal ini dapat disebabkan oleh beberapa faktor, antara lain seseorang dapat mengajukan perpindahan kewarganegaraan dengan berbagai alasan kepentingan orang tersebut. Adanya perkawinan campur dan kegiatan Usaha dapat menjadi alasan bagi seseorang untuk dapat mengajukan perubahan kewarganegaraan.

Perbedaan peraturan antara Penanaman Modal Dalam Negeri dan Penanaman Modal Asing tersebut menurut penulis dapat mengakibatkan adanya pergolakan hukum. dimana apabila Perseroan Terbatas Penanaman Dalam Negeri yang ingin melakukan kerjasamadan menarik penanam modal asing dalam perusahaannya maka Perseroan Terbatas tersebut wajib menambahkan modal dasarnya sekurangkurangnya minimal menjadi $\mathrm{Rp}$. 10.000.000.000,00 (sepuluh milliar Rupiah).

UU Penanaman Modal menjelaskan bahwa bagi penanaman modal dapat dilakukan dalam bentuk badan usaha yang berbentuk badan hukum, tidak berbadan hukum atau usaha perseorangan, sesuai dengan ketentuan peraturan perundang-undangan, dimana dengan berlakunya undang-undang ini juga menegaskan bahwasannya bentuk penanaman modal hanya terbagi atas Perusahaan Nasional yang bermodalkan Dalam Negeri, Perusahaan Nasional yang bermodalkan Asing/ campuran dan Perusahaan Asing. yang mana apabila adanya percampuran modal antara modal dalam negeri dengan modal asing maka Perusahaan tersebut langsung dikategorikan sebuah perusahaan Penanaman Modal Asing. ${ }^{19}$

Kegiatan menanam merupakan kegiatan untuk memasukkan modal atau investasi, dengan tujuan untuk melakukan kegiatan usaha. Kegiatan penanaman modal ini dilakukan oleh penanam modal

19 Iswi Hariyani Sefianto, Marger, Konsolidasi, Akuisisi, \& Pemisahan Perusahaan, Transmedia Pustaka, Jakarta, 2011, hlm. 25. 
asing, baik yang menggunakan modal asing sepenuhnya maupun modal yang berpatungan dengan penanam modal dalam negeri. Modal asing yang berpatungan merupakan modal asing yang bekerja sama dengan penanam modal Indonesia, di mana saham yang dimiliki oleh pihak asing maksimal 95\%, sedangkan pihak penanam modal Indonesia minimal 5\%.

Prosedur pendirian Perusahaan Penanaman Modal Asing di Indonesia sesuai Peraturan Kepala Badan Koordinasi Penanaman Modal Nomor 5 Tahun 2013 Tentang Pedoman dan Tata Cara Perizinan dan Non Perizinan Penanaman Modal (Perka BKPM 5/2013), prosedur pendirian perusahaan Penanaman Modal Asing dapat dibagi atas 2 bagian, yaitu : 1) Pendirian perusahaan baru; 2) Penyertaan pada perusahaan dalam negeri yang telah ada.

Dapat disimpulkan bahwa setiap Perusahaan yang didalamnya terdapat Modal Asing, tanpa melihat batasan jumlah modal tersebut dapat dikategorikan sebagai Penanaman Modal Asing. Berdasarkan ketentuan yang terdapat dalam Pasal 23 Perka BKPM 5/2013, setiap terjadinya perubahan struktur penanaman modal wajib melakukan pendaftaran penanaman modal ke Badan Koordinasi Penanaman Modal (BKPM).
Ketentuan tersebut diatas sekaligus menjadi bentuk perlindungan hukum bagi Warga Negara Asing yang memperoleh warisan berupa saham dalam Perseroan Terbatas non Penanaman Modal Asing. Hak ahli waris dalam hal ini tetap terlindungi karena Peraturan PerundangUndangan yang ada memberikan solusi bahwa dengan adanya perubahan struktur pemegang saham dalam perseroan yang beralih ke Warga Negara Asing maka status perseroan tersebut dapat diubah menjadi Perseroan Terbatas Penanaman Modal Asing sesuai dengan ketentuan yang ada di Indonesia.

\section{KESIMPULAN}

Sistem pewarisan di Indonesia menentukan bahwa pewarisan terjadi karena adanya hubungan darah dan hubungan perkawinan tanpa membedakan status kewarganegaraan ahli waris. Ahli waris Warga Negara Asing berhak atas warisan berupa saham dalam Perseroan Terbatas baik itu Perseroan Terbatas Penanaman Modal Dalam Negeri maupun Perseroan Terbatas Penanaman Modal Asing.

Peraturan Perundang-Undangan di Indonesia memberikan perlindungan hukum bagi Warga Negara Asing yang memperoleh saham dalam Perseroan Terbatas Penanaman Modal Dalam Negeri 
yaitu dengan melakukan perubahan status

Perseroan Terbatas Penanaman Modal

Dalam Negeri menjadi Perseroan Terbatas

Penanaman Modal Asing sehingga hak warga negara asing atas obyek waris yang jatuh kepadanya dapat tetap dimiliki.

\section{DAFTAR PUSTAKA}

\section{Buku-Buku}

Abdulkadir Muhammad, 2007, Hukum Perdata Indonesia, Citra Aditya Bakti, Bandung.

C.S.T. Kansil dan Cristine S.T. Kansil, 2008, Pokok-Pokok Pengetahuan Hukum Dagang Indonesia, Sinar Grafika, Jakarta.

David Kairupan, 2013, Aspek Hukum Penanaman Modal Asing di Indonesia, Kencana Prenada Media , Jakarta.

Habib Adjie, Penggabungan Peleburan \& Pengambil Alihan Dalam Perseroan Terbatas, Mandar Maju, Bandung.

Iswi Hariyani Sefianto, 2011, Marger, Konsolidasi, Akuisisi, \& Pemisahan Perusahaan, Transmedia Pustaka, Jakarta.

Man. S. Sastrawidjaja, 2008, Perseroan Terbatas Menurut Tiga UndangUndang, Alumni, Bandung.

Peter Mahmud Marzuki, 2005, Penelitian Hukum, Kencana Prenada Media Group, Jakarta.

Rudhi Prasetya, 2016, Perseroan Terbatas - Teori Dan Praktek, Sinar Grafika, Jakarta.
Sudikno Mertokusumo, 2002, Mengenal Hukum : Suatu Pengantar. Liberty, Yogyakarta.

Sudikno Mertokusumo, 2002, Penemuan Hukum, Liberty, Yogyakarta.

Tuti Rastuti, 2015, Seluk Beluk Perusahaan Dan Hukum Perusahaan, Refika Aditama, Bandung.

Yahya Harahap, 2016, Hukum Perseroan Terbatas, Sinar Grafika, Jakarta.

\section{Peraturan Perundang-Undangan}

Undang-Undang Nomor 25 Tahun 2007 Tentang Penanaman Modal (Lembaran Negara Republik Indonesia Tahun 2007 Nomor 67, Tambahan Lembaran Negara Republik Indonesia Nomor 4724).

Undang-Undang Nomor 40 Tahun 2007 tentang Perseroan Terbatas (Lembaran Negara Republik Indonesia Tahun 2007 Nomor 106, Tambahan Lembaran Negara Republik Indonesia Nomor 4756).

Undang-Undang Nomor 20 Tahun 2008 tentang Usaha Mikro, Kecil dan Menengah (Lembaran Negara Republik Indonesia Tahun 2008 Nomor 93, Tambahan Lembaran Negara Republik Indonesia Nomor 4866).

Peraturan Presiden Republik Indonesia Nomor 44 Tahun 2016 Tentang Daftar Bidang Usaha Yang Tertutup Dan Bidang Usaha Yang Terbuka Dengan Persyaratan Di Bidang Penanaman Modal (Lembaran Negara Republik Indonesia Tahun 2016 Nomor 97). 
Peraturan Kepala Badan Koordinasi Penanaman Modal Republik Indonesia Nomor 5 Tahun 2013 Tentang Pedoman Dan Tata Cara Perizinan Dan Nonperizinan Penanaman Modal (Berita Negara Republik Indonesia Tahun 2013 Nomor 584).

\section{Jurnal Dan Karya Ilmiah}

Hatta Isnaini Wahyu Utomo, "Hukum Perseroan”, Bahan Ajar, Fakultas Hukum, Universitas Yos Soedarso Surabaya, 2017.

Ika Febriasari Dan Afdol, "Kedudukan Keponakan Sebagai Ahli Waris Pengganti Dalam Sengketa Waris Melawan Anak Angkat Penerima Wasiat Wajibah", Jurnal Al-Adl, Volume X Nomor 1, Januari 2018.

Mariano Putra Prayoga Sumangkut dan Ghansham Anand, "Perbuatan Melawan Hukum Dalam Peralihan Aset Yayasan Keagamaan Yang Diperoleh Melalui Hibah Bersyarat Tanpa Akta Otentik (Kajian Putusan Nomor 2016 K/Pdt/2013)", Jurnal Al-Adl, Volume IX Nomor 3, Desember 2017.

Yati Nurhayati dan Ifrani, " The Legal Consequences Regarding The Execution Of Joint Property Land Obtained Due Transnatiional Marriage In Indonesian Positive Law" Lambung Mangkurat Law Journal, Vol. 3 Issue 1, March (2018) http://lamlaj.ulm.ac.id/web/index.p hp/abc/article.

Nurhayati, Yati. "TINJAUAN YURIDIS TERHADAP BUMN YANG BERBENTUK PERSEROAN TERBATAS (PT) DALAM PERKARA KEPAILITAN DIHUBUNGKAN DENGAN ASAS KEPASTIAN HUKUM." AL'ULUM 64.2 (2015).

Nurhayati, Yati. "Perdebatan antara Metode Normatif dengan Metode Empirik dalam Penelitian Ilmu Hukum Ditinjau dari Karakter, Fungsi, dan Tujuan Ilmu Hukum." Al Adl: Jurnal Hukum 5.10 (2013). 